\title{
Immunophenotyping of peripheral blood mononuclear cells and intracellular detection of IL-2, IFNy and IL-4 by flow cytometry in patients with actinomycetoma by Nocardia brasiliensis and Actinomadura madurae. Findings in six patients
}

\author{
Heuze de Icaza Ivonne ${ }^{1,6}$, Castrillón Rivera Laura Estela ${ }^{1,7}$, Garibay-Escobar Adriana ${ }^{2,3}$, \\ Sandoval Trujillo Horacio ${ }^{1,7}$, Padilla Desgarennes Carmen ${ }^{4}$, Palma Ramos Alejandro', \\ Santos-Argumedo Leopoldo ${ }^{2}$

\footnotetext{
${ }^{1}$ Universidad Autónoma Metropolitana, Campus Xochimilco. Calzada del Hueso 1100, Villa Quietud, Coyoacán, México D. F. CP 04960. México;

${ }^{2}$ Department of Molecular Biomedicine, Centro de Investigacion y Estudios Avanzados del IPN. Ave. Instituto Politécnico Nacional No. 2508, Col. Zacatenco, CP 07360, México City, México;

${ }^{3}$ Universidad de Sonora. Hermosillo, Sonora, México;

${ }^{4}$ Laboratory of Mycology. Centro Dermatológico "Dr. Ladislao de la Pascua”, Servicios de Salud Pública of Distrito Federal. México City, México;

${ }^{5}$ Departamento de Biolgía, Facultad de Química, UNAM. Ciudad Universitaria, México D.F., México;

${ }^{6}$ Heuze de Icaza Yvonne is in the Program of Doctorate in Biological Sciences. Universidad Autónoma Metropolitana, México City, México;

${ }^{7}$ Laura E. Castrillón R and Horacio Sandoval T. are part of Tutorial Committee of Yvonne Heuze in the Program of Doctorate in Biological Sciences. Universidad Autónoma Metropolitana, México City, México.
}

Received 20 January 2011; revised 5 February 2011; accepted 18 February 2011.

\section{ABSTRACT}

Mycetoma is a chronic, granulomatous, progressive inflammatory disease; it usually involves the subcutaneous tissue after a traumatic inoculation of the causative organism. Mycetoma may be caused by true fungi or bacteria (actinomycetes) and hence it is classified as eumycetoma and actinomycetoma respectively. Mycetoma immunological studies have frequently addressed humoral aspects. Few reports have addressed the role of cellular immunity in humans, for this reason, we were interested in finding differences in the circulating population of mononuclear cells or in the ability of this pathology to produce cytokines after mitogen stimulation. In this study, immunophenotyping of peripheral blood mononuclear cells (PBMN) and intracellular detection by flow cytometry of IL-2, IFNy and IL-4 in patients with actinomycetoma by Nocardia brasiliensis and Actinomadura madurae were evaluated. We investigated the expression of T-cells (CD3, CD4 and CD8), B-cells (CD19), monocytes (CD14), and natural killer cells (CD16 and CD56) markers. CD69 and CD25 were used to monitor individual activated cell subsets. The percentage values of the cells were calculated. Our results indicated that PBMC from patients with mycetoma show similar percentages of circulating cells when compared with healthy donors. The expression of IL-2 receptor (IL-2R) by mitogen activation was similar in these two groups. These findings suggest that circulating lymphocytes are not affected by this pathology. Intracellular IL-4 was increased only in patients with mycetoma by $N$. brasiliensis, suggesting a TH2 profile; this observation has been reported by other authors.

Keywords: Actinomycetoma; Nocardia brasiliensis; Actinomadura madurae; Cytokines; $\mathrm{CD}_{4}^{+}$; $\mathrm{CD}^{+}$; $\mathrm{CD}^{+} 6^{+}$

\section{INTRODUCTION}

Mycetoma is a chronic, granulomatous, progressive inflammatory disease; it usually involves the subcutaneous tissue after a traumatic inoculation of the causa- 
tive organism. Mycetoma may be caused by true fungi or by bacteria (actinomycetes) and hence it is classified as eumycetoma and actinomycetoma respectively $[1,2]$. Tumefaction and formation of sinus tracts characterize mycetoma. The sinuses usually discharge purulent and seropurulent exudate containing microcolonies called grains. It may spread involving skin and the deep structures, resulting in destruction, deformity, and loss of function. In rare occassions it may be fatal $[3,4]$. The clinical presentation of mycetoma is almost identical, regardless of the causal organism. However, the progress is faster in actinomycetoma comparatively with eumycetoma. In eumycetoma, the lesion grows slowly, with clear defined margins and it remains encapsulated for a long period, whereas, in actinomycetoma the lesion is more inflammatory, more destructive, and it invades the bone at an earlier period [1,4]. Mycetoma lesion has a distinct appearance in a cytology smear which is characterized by the presence of inflammatory cells consisting of a mixture of neutrophils, lymphocytes, plasma cells, histiocytes, macrophages, and foreign body giant cells in grains [5]. In tissue sections, three types of tissue reactions have been described (I, II and III). Type I is characterized by actinomycetoma lesion $[6,7]$ where the grain is closely surrounded by polymorphonuclear leukocytes that are the predominant cell type in the inflammatory infiltrate in the skin lesions and occasionally infiltrated by neutrophils, causing its fragmentation. Outside the neutrophil zone, monocytic cells and giant cells are observed. The lymphocytes are scant where the main population is $\mathrm{TCD}^{+}[8]$.

Cenci et al. [9] demonstrated the cellular elements in the inflammatory infiltrate in skin lesions of actinomycetoma and eumycetoma and suggested that cellular mediated immunity may play a role in mycetoma pathogenesis, in which a marked reduction of Langerhans cells may reflect a depressed cell immune response, partially explaining a chronic condition and unresponsiveness to the treatment.

Studies on the immunopathologic aspects of tissue reaction are much less frequent, immunological studies of mycetoma have frequently addressed humoral aspects [10-13]. Few reports have addressed the role of cellular immunity in humans. The main studies regarding cellular immune response by delayed hypersensitivity to antigens from Nocardia was first describe in 1972 [14] and protective effect after spleen cell transfer from guinea pigs infected with Nocardia asteroids was demonstrated five years later [15]. A defective T-cell mediated response in eumycetoma patients was suggested as an important element in this pathology when the lymphocyte proliferation stimulated with phytohemagglutinin affected skin reactivity to dinitrochlorobenzene in these patients [16]; in contrast, infections by Nocardia asteroides did not show these efects [17].

Cell-mediated immunity plays a major protection role against intracellular microbes. Nocardia brasiliensis is a facultative intracellular pathogen that grows in macrophages but not in PMN leukocytes [18]. The mechanisms that allow explaining the evasion, resistance, or neutralization of bactericidal action of macrophages and neutrophils are: 1) production of high levels of catalase and superoxide dismutase that reduce the oxygen toxic products generated by phagocyte, 2) reduction of lysosome enzymatic activity of some macrophage populations, 3) blockade of phagosome acidification, and 4) inhibition of phagosome-lysosome fusion [19].

Regarding Actinomadura madurae infections, the ability of this bacteria to persist inside murine macrophages in experimental in vivo and in vitro infections has been reported [20]; as with nocardia infections, this could explain the tendency to chronicity by actinomycetales due their replicative capacity inside the phagocytes, probably this fact is related to blood dissemination as it was demonstrated in experimental mycetoma by Nocardia brasiliensis [21].

In mycetoma, the local host response is characterized by neutrophil chemotaxis and small vessel congestion. Initially, the response is nonspecific, later, macrophages and monocytes present at the infection site are activated by interferon gamma and tumor necrosis factor-alpha; these cells have enhanced microbicidal activity [22]. For these reasons, the production of pro-inflammatory and anti-inflammatory cytokines and the expression of their receptors, after stimulation are important indicators of mononuclear cell activation in this pathology.

\section{MATERIAL AND METHODS}

\subsection{Patients}

Mononuclear cells from four patients with mycetoma by Nocardia brasiliensis, two patients with mycetoma by Actinomadura madurae, and five healthy subjects were evaluated. These patients were diagnosed and treated by the Mycology Service of the Dermatologic Center "Ladislao de la Pascua" in Mexico City. This study was carried out with the written consent of all patients and it was approved by the Ethics Committees of each participating institution.

\subsection{Samples}

Peripheral blood samples from healthy volunteers and patients were collected in sodium heparin VACUTAINER $^{\mathrm{R}}$ tubes (Becton Dickinson, San Jose, CA). Percentages and absolute counts of mature human lym- 
phocytes subsets were evaluated from PBMC as follows: T lymphocytes $\left(\mathrm{CD}^{+}\right)$, B lymphocytes $\left(\mathrm{CD} 19^{+}\right)$, helper /inducer $\mathrm{T}$ lymphocytes $\left(\mathrm{CD}^{+} \mathrm{CD}^{+}\right)$, cytotoxic $\mathrm{T}$ lymphocytes $\left(\mathrm{CD}^{+} \mathrm{CD}^{+}\right)$, and natural killer (NK) lymphocytes (CD3-CD16 + CD56 ${ }^{+}$). CD69 is expressed on all activated lymphocytes, thus it represents a generic marker to monitor individual subset responses to different stimuli [23].

\subsection{CD25 (IL-2 $\alpha \mathrm{R}$ ) Expression}

PBMC were stimulated with $20 \mu \mathrm{g} / \mathrm{mL}$ phytohaemaglutinin (PHA Sigma) in RPMI, in 24 well flat bottom plates (Corning Glass Works, Corning, NY) for $24 \mathrm{~h}$ at $37^{\circ} \mathrm{C}$ and $5 \% \mathrm{CO}_{2}$. After incubation, PBMC were harvested by centrifugation at $500 \times \mathrm{g}$ for $5 \mathrm{~min}$ and then stained with a three-color combination using the following mAbs: anti-CD25PE (IL-2R) (Phar Mingen), antiCD4FITC (Phar Mingen) and anti-CD3PerCP (Immmunotech, Marseille, France). Percenteges of $\mathrm{T}$ lymphocytes (gated on $\mathrm{CD}^{+}$) expressing CD25 were measured by flow cytometry.

\subsection{Intracellular Cytokine Detection: IFN-Y, IL-2 and IL-4 [24]}

The production of cytokines was measured through intracellular staining. Briefly, capped polystyrene Falcon tubes (Becton Dickinson) were used to incubate whole blood samples with $25 \mathrm{ng} / \mathrm{ml}$ phorbol myristate acetate (PMA) (Sigma), $1 \mu \mathrm{g} / \mathrm{ml}$ ionomycin (Sigma), and 10 $\mu \mathrm{g} / \mathrm{ml}$ brefeldin A (BFA) (Sigma) or BFA only (control), for $5 \mathrm{~h}$ at $37^{\circ} \mathrm{C}$ and $5 \% \mathrm{CO}_{2}$. Anti-CD3 peridinin chlorophyll protein (PerCP) (Becton Dickinson) was added to aliquots of the stimulated and non-stimulated blood and then incubated for $15 \mathrm{~min}$ at room temperature in the dark. After incubation, erythrocytes were lysed with FACS lysing solution (Becton Dickinson) and the samples were incubated for another $10 \mathrm{~min}$ at room temperature in the dark. The cells were then centrifuged for $5 \mathrm{~min}$ at $500 \times \mathrm{g}$ and supernatants were aspirated without disturbing the pellets. FACS permeabilizing solution (Becton Dickinson) was added to the pellets and incubated for $10 \mathrm{~min}$ at room temperature in the dark; cell suspensions were then washed with phosphate buffered saline (PBS) containing $0.1 \%$ bovine serum albumin (BSA) (Research Organics, Cleveland, $\mathrm{OH}$ ) and $0.01 \%$ sodium azide (PBA), and centrifuged for $5 \mathrm{~min}$ at $500 \times$ $\mathrm{G}$, the supernatants were removed. For intracellular staining, anti-cytokine monoclonal antibodies (mAbs) were added to the pellets and cell suspensions were incubated at room temperature for $30 \mathrm{~min}$ in the dark, ac- cording to the following protocol: FastImmune ${ }^{\mathrm{R}}$ INF- $\gamma$ fluorescein isothiocyanate (FITC)/IL-4 phycoerythrin (PE)
(Becton Dickinson) or FastImmune ${ }^{\mathrm{R}}$ anti-HuIL-2 FITC (Becton Dickinson), and anti-CD69PE (Becton Dickinson) were added to the pellets previously stained with anti-CD3PerCP. Simultest $\gamma_{2 \mathrm{a}}$ FITC $/ \gamma_{1}$ PE with anti-CD3 PerCP was used as isotype control.

For all conditions, the expression of CD69 was measured as an activation control. The samples were washed with PBA and fixed with PBS containing 1\% paraformaldehyde (PFA). A fluorescent activated cell sorter FACSCalibur $^{\mathrm{R}}$ (Becton Dickinson) equipped with a 15 $\mathrm{mW}$ argon ion laser and filter settings for FITC $(530 \mathrm{~nm})$, PE (585 nm) and PerCP(Becton Dickinson), emitting in the deep red $(>650 \mathrm{~nm})$ was used. Cells $(10,000)$ were computed in list mode and analyzed gating on CD3 (lymphocytes) using the CellQuest ${ }^{\mathrm{R}}$ software.

\section{Results}

\subsection{Mononuclear Cell Populations}

The analysis of mononuclear cell populations in normal subjects and from patients with mycetoma by $\mathrm{No}$ cardia brasiliensis and Actinomadura madurae is presented in Table 1. The results from healthy volunteers showed: $\mathrm{CD}^{+} \mathrm{T}$ cells $(84 \%)$, in which the percentages for the subpopulations were $\mathrm{TCD}^{+}(56.6 \%), \mathrm{TCD}^{+}$ (28.2\%); B cells $(13.2 \%)$; NK cells and monocytes both were at $1 \%$. In mycetoma patients, the percentages were as follows: $\mathrm{T}$ lymphocytes $\left(\mathrm{CD}^{+}\right)$were $84.7 \%$, in which $58.1 \%$ and $26.6 \%$ corresponded to $\mathrm{CD}^{+}$and $\mathrm{CD} 8+$ lymphocytes, respectively. B lymphocytes were $12.3 \%$, NK cells $1 \%$ and monocytes $0.6 \%$.

\subsection{IL-2AR Expression Analysis}

A kinetic analysis for the expression of $\mathrm{CD} 25^{+}$ (IL-2 $\alpha \mathrm{R}$ ) was made. PBMC from healthy subjects were stimulated with $20 \mu \mathrm{g} / \mathrm{mL}$ PHA for $0,24,48$ and $72 \mathrm{~h}$ and stained for CD25 (IL-2 $\alpha$ R). Percentages of lymphocytes positive for CD25 were mesured at each time by

Table 1. Percentage of monocytes (CD14+), NK (CD16 + $\mathrm{CD} 56+), \mathrm{TCD} 8+(\mathrm{CD} 3+)$ and $\mathrm{B}(\mathrm{CD} 19+)$ lymphocytes from total $\mathrm{PBMC}$ in healthy and actinomycetoma patients.

\begin{tabular}{ccccc}
\hline Monocytes & $\mathrm{CD} 3+$ & $\mathrm{CD} 3+$ & $\mathrm{NK}$ & $\mathrm{B}$ \\
$\%$ & $\mathrm{CD} 4+$ & $\mathrm{CD} 8+$ & $\%$ & $\%$ \\
$(\mathrm{CD} 14+)$ & $\%$ & $\%$ & $\mathrm{CD} 16+$ & $(\mathrm{CD} 19+)$ \\
\hline
\end{tabular}

Patients with mycetoma by

Nocardia brasiliensis

$0.15 \pm 0.0858 .4 \pm 13.3 \quad 25 \pm 12.0 \quad 2.0 \pm 1.2 \quad 14.5 \pm 10.4$

Actinomadura $1.1 \pm 1.6 \quad 57.8 \pm 11.928 .3 \pm 14.92 .4 \pm 1.8 \quad 10.2 \pm 10.1$ madurae

Healthy donors

$1.0 \pm 1.9 \quad 56.6 \pm 13.7 \quad 28.2 \pm 1.9 \quad 1.0 \pm 1.2 \quad 13.2 \pm 6.7$ 


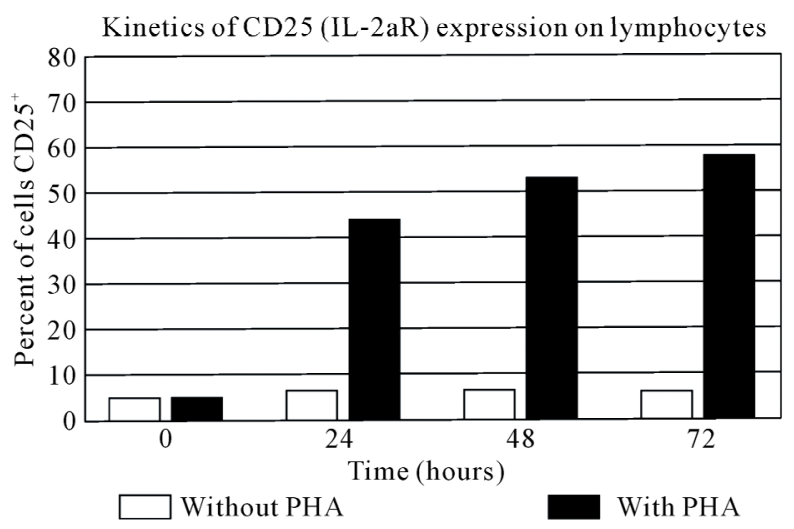

Figure 1. Percent of expression of IL-2 $\alpha \mathrm{R}$ at different hours of stimulation.

flow cytometry. As it can be seen in Figure 1, maximum expression of IL- $2 \alpha \mathrm{R}\left(58.66 \% \mathrm{CD} 25^{+}\right)$was detected after $72 \mathrm{~h}$ of activation; however, at this time, the percentage of cell death was also high $(60 \%$ of cells were positive for propidium iodide staining, data no shown). For this reason, all determinations were done after $24 \mathrm{~h}$ of stimulation.

\subsection{Percentages of TCD4 ${ }^{+}$Lymphocytes from Healthy Donors, and Mycetoma Patients Expressing IL-2aR (CD25 ${ }^{+}$)}

The percentages of $\mathrm{CD}^{+} \mathrm{T}$ cells expressing IL-2 receptor $\left(\mathrm{CD} 25^{+}\right)$showed that $6.3 \%$ of healthy donors expressed CD25 upon activation; in contrast, $15.3 \%$ and $13.3 \% \mathrm{CD}^{+}$lymphocytes from patients suffering mycetoma by Nocardia brasiliensis or by Actinomadura madurae respectively were positive for this molecule.

Table 2.

\subsection{Detection of the Intracellular Cytokines: IL-2, IFN-Y and IL-4}

Lymphocytes from healthy donors, (gated on $\mathrm{CD}^{+}$cells) expressed CD69 (12.81\%), IL-2 (3.19\%), IFN- $\gamma$ (17.34 $\%)$ and IL-4 (0.43\%), only when they were activated with PMA and ionomycin (Table 3). The absence or low

Table 2. Percentage of TCD4+ lymphocytes from healthy donors and actinomycetoma patients, expressing IL-2 $\alpha \mathrm{R}(\mathrm{CD} 25+)$.

\begin{tabular}{lccc}
\hline \multirow{2}{*}{$\begin{array}{l}\text { Patients with } \\
\text { mycetoma by }\end{array}$} & \multicolumn{3}{c}{$\begin{array}{c}\text { Percentage of positive cells } \\
\text { (IL-2 } \alpha \mathrm{R})\end{array}$} \\
\cline { 2 - 4 } & $\mathrm{CD} 4+$ & CD25+ & CD4+ - CD25+ \\
\hline $\begin{array}{l}\text { Nocardia brasiliensis } \\
\text { Actinomadura } \\
\text { madurae }\end{array}$ & $58.4 \pm 13.3$ & $21.5 \pm 13.2$ & $15.3 \pm 7.2$ \\
Healthy donors & $57.8 \pm 11.9$ & $16.4 \pm 11.6$ & $13.3 \pm 2.7$ \\
\hline
\end{tabular}

Table 3. Percentage of lymphocytes expressing CD69 and producing cytokines upon stimulation.

\begin{tabular}{lcccc}
\hline \multirow{2}{*}{$\begin{array}{l}\text { Patients with } \\
\text { mycetoma } \\
\text { by }\end{array}$} & \multicolumn{4}{c}{ CD3 + lymphocytes expressing } \\
\cline { 2 - 5 } & $\mathrm{CD} 69+$ & IL-2 (\%) & IFN- $\gamma(\%)$ & IL4 (\%) \\
\hline $\begin{array}{l}\text { Nocardia } \\
\text { brasiliensis }\end{array}$ & $13.3 \pm 3.2$ & $5.7 \pm 3.5$ & $17.3 \pm 18.4$ & $3.7 \pm 2.6$ \\
$\begin{array}{l}\text { Actinomadura } \\
\text { madurae }\end{array}$ & $13.3 \pm 2.3$ & $4.9 \pm 0.9$ & $15.9 \pm 13.0$ & $0.4 \pm 0.4$ \\
$\begin{array}{l}\text { Healthy } \\
\text { donors }\end{array}$ & $12.8 \pm 6.3$ & $3.2 \pm 2.1$ & $17.3 \pm 10.7$ & $0.4 \pm 0.4$ \\
\hline
\end{tabular}

levels of IL-4 production, confirms the difficulty of detecting this Th2-type cytokine by flow cytometry [25]. Table 3 also shows the expression of these cytokines in six patients. An average of $14.2 \%$ of $\mathrm{T}$ cells expressed CD 69 , while $5.9 \%$ of these produced IL-2, $15.7 \%$ produced IFN- $\gamma$ and $0.68 \%$ produced IL-4.

\section{Discussion}

Although mycetoma was first described more than 3,000 years ago, the studies on physiopathology began only some decades ago. Many aspects about the immune response during the evolution of this disease are still unknown. A basic question related to the nature of the immunological response in this pathology could be related to the existence of differences in the circulating mononuclear cells in these patients. In our analysis, peripheral blood monocytes, $\mathrm{CD}^{+}$and $\mathrm{CD}^{+} \mathrm{T}$ lymphocytes and natural killer cells $\mathrm{CD}^{+} 6^{+}$were present with similar values in patients as well as control subjects (Table 1). This fact suggests that the immune response is developed locally and the patients that suffer this chronical disease do not present changes in circulating mononuclear cells (Figure 2).

Host immune response is present in both, human (natural infection) and experimental infections (animal models or in vitro) with Nocardia brasiliensis and Actinomadura madurae. The response is characterized by an intense infiltration of polymorphonuclear cells, being this a constant finding during the entire active infection [26]. Infections by Nocardia have been associated with: a) inhibition of the bacteria by monocytes and polymerphonuclear leukocytes, b) activation of macrophages and 3 ) specific cytotoxicity from a T cell subset [27]. However,in the long run, Nocardia depends on the metabolic state of macrophage and neutrophil, the concentration and type of lysosomal enzymes inside the cell and the type of strain of Nocardia [17] and also, probably, the presence of $\mathrm{L}$ forms of bacteria inside cells involved in tissue process [28]. A deficiency of one of these factors could augment the host's subseptibility to acquire the illness produced by this bacterium. The ideal candidates to modulate these functions are the cytokines which 


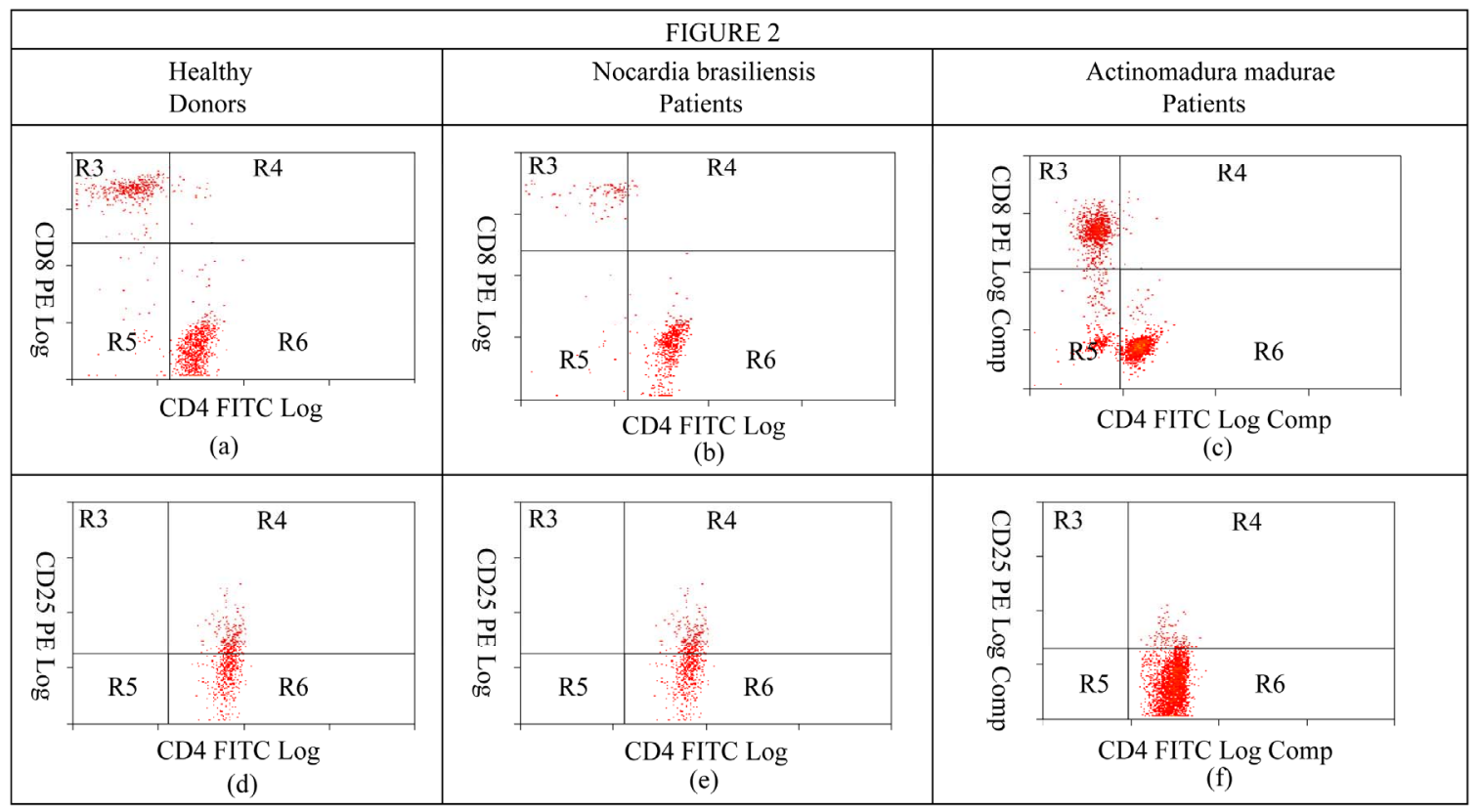

Figure 2. Percentage from PBMC evaluated by flow cytometry from mononuclear peripheral blood from healthy volunteers (a) and (d); with mycetoma by Nocardia brasiliensis patients (b) and (e); and Actinomadura madurae patients (c) and (f). PBMC were stimulated with $20 \mu \mathrm{g} / \mathrm{mL}$ phytohaemaglutinin in RPMI, for $24 \mathrm{~h}$ at $37^{\circ} \mathrm{C}$ and $5 \%$ $\mathrm{CO}_{2}$, then the cells were stained with: anti-CD25PE, anti-CD4FITC, anti-CD8PE and anti-CD3PerCP. Percentages of $\mathrm{T}$ lymphocytes (gated on $\mathrm{CD}^{+}$) expressing CD25 were measured by flow cytometry.

are proteins that regulate the origin, proliferation and activation of the immune cellular response.

There is a wide range of disease severeness for many human pathologic conditions; it is likely to be a spectrum of cytokine production, imbalance, or cytokine dysregulation, at different stages of the disease. In infections like mycetoma, IFN- $\gamma$ may induce or activate bactericidal mechanisms of infected macrophages and clear the infection. It may induce TH1 lymphocyte proliferation, activate macrophages and reduce the production of other interleukins such as IL-4 and IL-10. In an experimental actinomycetoma model in mice, it was demonstrated that circulating IFN- $\gamma$ levels increased 10 times the basal levels during the 4 days of infection and decreased with the progression of the disease [29].

The identification of a specific cell surface marker for type 1 or type 2 cytokine-producing cells or the ability to stain intracellulary such cytokines would greatly facilitate the study of these cells and their role in human diseases. Direct intracellular detection of cytokines by flow cytometry has been accomplished, in some cases in combination with cell surface marker expression [30]. In this work, intracellular cytokines produced by stimulated $\mathrm{T}$ lymphocytes from patients with mycetoma showed an adequate response to activation. Similar percentages of IFN- $\gamma$ producing cells were detected in both healthy donors and patients. These results demonstrate that cellular immune response of patients is not affected by the pa- thology, at least in these cytokines, as shown in Figure 3.

Instead the cytokine quantification, the study of receptor activity may be a more suitable indicator of cellular activation ability. The measurement of functional receptors by the binding of labeled cytokine has been reported [25]; in mycetoma patients, the expression of IL-2 receptor (CD25) by PHA stimulation showed an increase in patients, this finding demonstrates that patient's $\mathrm{CD} 3^{+} \mathrm{CD} 4^{+} \mathrm{CD} 25^{+}$cells are able to bind to IL-2 and consequently to be stimulated for proliferation and activation (Table 2).

There is an inverse relationship between cell-mediated (CMI) and humoral immunity in response to antigenic stimuli. TH1 cells are recongnized to provide a better helper activity for CMI whereas $\mathrm{TH} 2$ cells are more important for B-cell development and antibody production. Human illnesses regarding type 1 and type 2 cytokine imbalances may explain part of the pathology in this disease; thus restoring the balance may ameliorate the disease [31]. The profile of TH1-TH2 responses in mycetoma is unknown.

TH2 cytokines also induce IgE production and eosinophilia. These responses are characteristic of helminth infections, atopic disorders, and uncontrolled infections with intracellular pathogens (e.g. visceral leishmaniasis and lepromatous leprosy) [32].

In this study, T-lymphocytes producing IL-4 were 


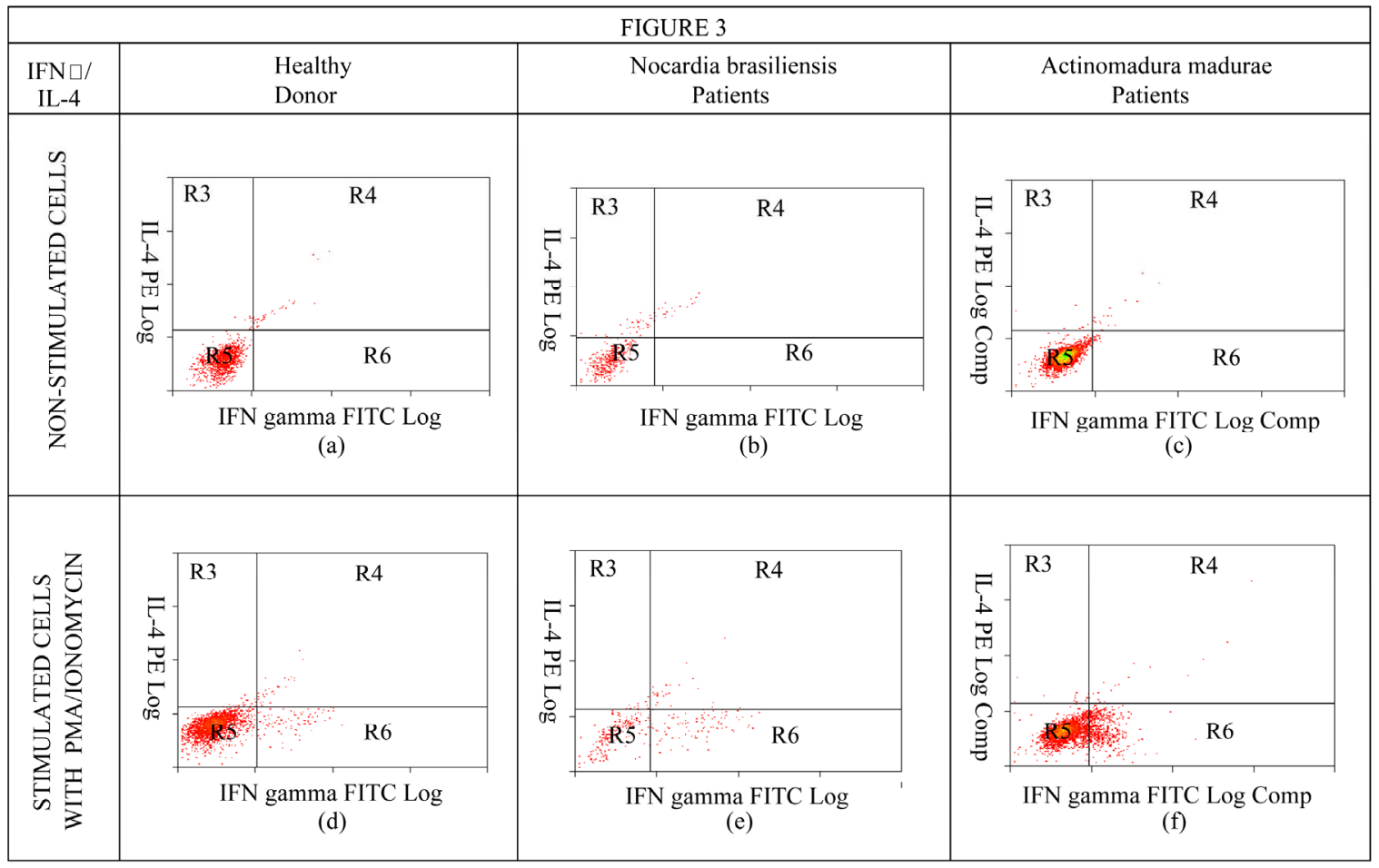

Figure 3. Intracelular cytokines produced by stimulated $\mathrm{T}$ lymphocytes of healthy donor (a) and (d), Nocardia brasiliensis (b) and (e), and Actinomadura madurae patients (c) and (f). Whole blood was incubated with $25 \mathrm{ng} / \mathrm{mL}$ PMA, $1 \mu \mathrm{g} / \mathrm{mL}$ ionomycin and $10 \mu \mathrm{g} / \mathrm{mL}$ BFA for $5 \mathrm{H}$, then linage was determined by surface staining (CD3). Panels (a), (b) and (c) are non-stimulated cells, and (d),(e) and (f), are stimulated cells.

higher only in the patients with $N$. brasiliensis infection; in contrast, the cells from $A$. madurae patients were normal. This fact probably indicates that $\mathrm{TH} 2$ profile is present in actinomycetoma Nocardia patients. This type of immune response may favor the disease progression. These observations are in agreement with the study of El Hassan [33] who demonstrated the TH2 cytokine pattern in lymph nodes from patients suffering mycetoma by Streptomyces somaliensis, as well as the cytokine production analysis in patients with actinomycetoma caused by Nocardia brasiliensis [34] However, further studies in actinomycetoma are needed to determine the production of other cytokines (TNF $\alpha$, IL-10).

\section{ACKNOWLEDGMENTS}

The authors thank M. Sc. Hector Romero Ramirez, DVM Jorge Fernández Hernández, and QFB Victor Hugo Rosales Garcia for their help at different stages of this work.

\section{REFERENCES}

[1] Welsh, O., Vera-Cabrera, L. and Mejía, M.A. (2007) Aspectos clínicos, radiológicos y terapéuticos del actinomicetoma. In: En Serrano, J.A., Sandoval, H. and Beaman, B.L., Eds., Actinomicetoma. Plaza y Valdés,
México DF.

[2] Castrillón, R.L., Palma, R.A. and Sampedro, P.J.G. (1998) Actinomicetoma. Bioquimia.

[3] Mahgoub, E.S. and Murray, I.G. (1973) Mycetoma. Medical Books Ltd., William Heinemann, London.

[4] Magaña, M. (1984) Mycetoma. International Journal of Dermatology, 23, 221-236. doi:10.1111/j.1365-4362.1984.tb01238.x

[5] EL Hag, I.A., Fahal, A.H. and Khalil, E.A.G. (1996) Fine needle aspiration cytology of mycetoma. Acta Cytologica, 40, 461-464.

[6] Fahal, A.H., El Toum, E.A., Gumaa, S.A., Mahgoub, E.S. and El-Hassan, A.M. (1995) Host tissue reaction to Madurella mycetomatis: New classification. Journal of Medical and Veterinary Mycology, 33, 103-106. doi:10.1080/02681219580000041

[7] Fahal, A.H. (2004) Mycetoma: A thorn in the flesh. Transactions of the Royal Society of Tropical Medicine and Hygiene, 98, 3-11. doi:10.1016/S0035-9203(03)00009-9

[8] Palma-Ramos, A, Castrillón-Rivera, L.E., Pizaña-Cureño, A., Vega-Memije, M.E., López-Bárcenas, A.P., Arenas-Guzmán, R. and Padilla-Desgarennes, M.C. (2007) Subpoblaciones de linfocitos $\mathrm{T}$ en el micetoma. Dermatología Rev Mex, 51, 212-218.

[9] Cenci, G.C., Castro, M.L.G. and Sotto, N.M. (2003) Lymphocyte subsets, macrophages and Langerhans cells in actinomycetoma and eumycetoma tissue reaction. Acta 
Tropica, 87, 377-384. doi:10.1016/S0001-706X(03)00139-6

[10] Humpreys, D.W., Crowder, J.G. and White, A. (1975) Serological reactions to Nocardia antigens. American Journal of Science, 269, 323-336.

[11] Salinas-Carmona, M.C. (2001) Anticuerpos anti-Nocardia brasiliensis en pacientes con actinomicetoma y su utilidad clínica. Gac Med Mex, 137, 1-8.

[12] Salinas-Carmona, M.C. and Pérez-Rivera, I. (2004) Humoral Immunity through IgM protects mice from an experimental mycetoma infection by Nocardia brasiliensis. Infection and Immunity, 72, 5597-5604. doi:10.1128/IAI.72.10.5597-5604.2004

[13] Araujo, M.J. and Castaneda, E. (1997) Madurella mycetomatis for the serodiagnosis of mycetoma. Revista Iberoamericana de Micología, 14, 31-35.

[14] Ortíz-Ortíz, L. and Bojalil, L.F. (1972) Delayed skin reactions to cytoplasmic estracts of Nocardia organisms as a means of diagnosis and epidemiological study of Nocardia infections. Clinical \& Experimental Immunology, 12, 225-229.

[15] Sundararag, T. and Agarwal, S.C. (1977) Cell-mediated immunity in experimental Nocardia asteroides infection. Infection and Immunity, 15, 370-375.

[16] Mahgoub, E.S., Gumaa, D.A. and El Hassan, A.M. (1977) Immunological status of mycetoma patients. Bull Soc Pathol Exot., 70, 48-54.

[17] Beaman BL, Beaman L. Nocardia species: Host-parasite relationships. Clin Microbiol Rev. 1994; 7:48-54.

[18] Beaman BL. Possible mechanisms of nocardial pathogenesis. In: Biology of the nocardiae pag 386-417. Ed Brownell G, Goodfellow M, Serrano JA. Academic Press London 1976.

[19] Beaman BL, Black C. Interaction of Nocardia asteroides in BALB/c mice: Modulation of macrophage function, enzyme acvtivity and the induction of immunologically specific T-cell bactericidal activity. Curr Topics Microbiol. 1985; 122:138-147.

[20] Castrillón RLE, Palma RA, Sampedro PGJ. Interacción de Actinomadura madurae con macrófagos peritoneales murinos. Rev Centro Dermatol Pascua. 1998; 7:37-43.

[21] Palma RA, Cuevas MMV, Areanas GR, Vega MME, Castrillón RLE. Diseminación hematógena por Nocardia brasiliensis en tres ratones $\mathrm{Balb} / \mathrm{c}$ a partir de un micetoma en cojinete plantar. Dermatol Rev Mex. 2008; 52:70-76.

[22] López BAP, Arenas GA, Vega MME, Castrillón RLE, Palma RA. Identificación de células y mediadores inflamatorios en lesiones de pacientes con diagnóstico de micetoma. Dermatol Rev Mex. 2008; 52:247-53.

[23] Testi R, D'Ambrosio D, De Maria R, Santoni A. The CD69 receptor: a multipurpose cell-surface tigger for hematopoietic cells. Immunol Today. 1994; 15:479-483. doi:10.1016/0167-5699(94)90193-7

[24] Garibay-Escobar, A., Estrada-García, I., Estrada-Parra, S., Santos-Argumedo, L. Integrated measurements by flow cytometry of the cytokines IL- 2 , IFN- $\gamma$, IL-12, TNF- $\alpha$ and functional evaluation of their receptors in human blood. J Immunol. Methods. 2003; 280:73-88. doi:10.1016/S0022-1759(03)00249-7

[25] Collins, D. O. Cytokine and cytokine receptor expression as a biological indicator of immune activation: important considerations in the development of in vitro model systems. J Immunol Methods. 2000; 243:125. doi:10.1016/S0022-1759(00)00218-0

[26] Salinas-Carmona MC. Nocardia brasiliensis: from microbe to human and experimental infections. Microbes and Infect. 2000; 2:1373-1381. doi:10.1016/S1286-4579(00)01291-0

[27] Calcagno M. Status inmunológico del paciente con micetoma. Dermatol Ven 1989: 27:49-52.

[28] Beaman BL, Scates SM. Role of L-forms of Nocardia caviae in the development of chronic mycetomas in normal and immunodeficient murine models". Infect. Immun. 1981, 33 (3): 893-907.

[29] Salinas-Carmona MC, Torres-López E, Ramos AI, Lincon-Trujillo González Spencer D. Immune response to Nocardia brasiliensis antigens in an experimental model in actinomicetoma in Balb/c mice. Infect Immun. 1999; 67:2428-2432.

[30] Elson HL, Nutman BT, Metcalfe DDF, Prussin C. Flow cytometry analysis for cytokine production identifies $\mathrm{T}$ helper $1, \mathrm{~T}$ helper 2 and $\mathrm{T}$ helper 0 cells within the human CD4 + CD27- lymnphocyte subpopulation. J Immunol. 1995; 154:4294-4301.

[31] Lucey RD, Clerici M,Shearer MG. Type 1 and Type 2 cytokine dysregulation in human infectious, neoplastic and inflammatory disease. Clin Microbiol Rev. 1996; 9:532-562.

[32] Yamamura M, Uyemura K Deans RJ, Weinberg K, Rea TH, Bloom RB, Moldin RL. Defining protective reponses to pathogens: cytokine profiles in leprosy lesions. Science $1991 ;$ 254:277-279. doi:10.1126/science. 1925582

[33] El Hasssan AM, Fahal AH, Ahmed AO, Ismail A, Veress B. The immunopathology of actinomycetoma lesions caused by Streptomyces somaliensis. Trans R Soc Trop Hyg 2001; 95:89-92. doi:10.1016/S0035-9203(01)90346-3

[34] Méndez-Tovar LJ, Mondragón-López R, Vega-López F, Dockrell MH, Hay R, López-Martínez R, Manzano- Gayosso P, Hérnández-Hernández F, Padilla-Desgarennes $\mathrm{C}$, Bonifaz A. Cytokine production and lymphocyte proliferation in patients with Nocardia brasiliensis actinomycetoma. Mycopathologia 2004; 58:407-414. 